\title{
Molecular characterization of a ranavirus isolated from largemouth bass Micropterus salmoides
}

\author{
Jinghe Mao ${ }^{1}$, Jun Wang ${ }^{1}$, Giovina D. Chinchar ${ }^{2}$, V. Gregory Chinchar ${ }^{1, *}$ \\ ${ }^{1}$ Department of Microbiology, University of Mississippi Medical Center, Jackson, Mississippi 39216, USA \\ ${ }^{2}$ Division of Natural Sciences, Tougaloo College, Jackson, Mississippi 39174, USA
}

\begin{abstract}
An iridovirus, isolated from largemouth bass Micropterus salmoides following a die-off among adult fish and provisionally designated largemouth bass virus (LMBV), was characterized by analysis of viral protein synthesis in infected cells, viral DNA restriction fragment length polymorphisms (RFLP), and sequence determination of the major capsid protein and viral DNA methyltransferase genes. All 3 approaches yielded results consistent with the suggestion that LMBV was a member of the genus Ranavirus. Moreover, LMBV was nearly identical to 2 isolates from Southeast. Asia which had been previously detected in imported ornamental fish. It remains to be determined whether infection of largemouth bass resulted from exposure to an imported virus, or whether the presence of similar viruses in southeast Asia and the southeastern United States indicates that iridovirus species are not geographically limited as suggested earlier, but rather globally distributed.
\end{abstract}

KEY WORDS: Largemouth bass Micropterus salmoides - Ranavirus - Iridovirus Fish die-off - Viral taxonomy

\section{INTRODUCTION}

Iridoviruses are important pathogens in freshwater and saltwater fish. Up until the mid-1980s, iridovirus infections in fish were solely attributable to 1 agent, fish lymphocystis disease virus (LCDV), the type species of the genus Lymphocystivirus (Weissenberg 1965, Anders 1989). LCDV infects $\sim 100$ species of marine and freshwater fish, and is responsible for a clinical disease characterized by the presence of wartlike growths on the skin and (less commonly) internal organs (Wolf 1988). In contrast to papillomavirus infections in mammals, where hyperplasia is the cause of benign growths (Shah \& Howley 1990), LCDV-induced lesions represent individual infected connective tissue cells that have undergone a massive increase in cell volume. Although LCDV infections are unsightly, they spontaneously regress and mortality is generally very low.

\footnotetext{
- Addressee for correspondence.

E-mail:vchinchar@microbio.umsmed.edu
}

Within the last 12 yr several novel iridoviruses have been isolated and shown to be responsible for significant morbidity and mortality among a variety of fish species (Langdon et al. 1986, Ahne et al. 1989. Armstrong \& Ferguson 1989, Hedrick et al. 1992a,b, Inouye et al. 1992, Pozet et al. 1992, Hedrick \& McDowell 1995, Plumb et al. 1996, Mao et al. in press). In contrast to LCDV, most of these agents cause severe systemic infections involving multiple internal organs. Although novel iridoviruses were isolated from several fish species, clinical disease varied among different species. For example, epizootic hematopoietic necrosis (EHNV) virus causes severe disease with high mortality in redfin perch, only low levels of mortality in rainbow trout, and no apparent disease in several other species (Langdon et al. 1986, Langdon 1989). Using a battery of molecular tests including DNA sequence analysis, Mao et al. (1997) showed that 6 novel fish iridoviruses were members of the genus Ranavirus and were more closely related to frog virus 3 , the type species of that genus, than to LCDV. 
In 1995, following a die-off of about a thousand adult largemouth bass in South Carolina's Santee-Cooper reservoir, an iridovirus, provisionally designated largemouth bass virus (LMBV), was identified as the putative etiological agent by electron microscopy, PCR (polymerase chain reaction), and indirect fluorescent antibody assay (Plumb et al. 1996). In addition, the clinical presentation (i.e. systemic infection rather than external lesions) suggested that LMBV was a ranavirus rather than a lymphocystivirus. To confirm its putative designation as a ranavirus and to determine its taxonomic position within the family Iridoviridae, we characterized this agent by analyzing viral protein synthesis in infected cells, restriction fragment length polymorphisms within viral DNA, and the nucleotide sequence of the major capsid protein (MCP) and DNA methyltransferase genes. These results confirm that LMBV is a member of the genus Ranavirus and indicate that it is nearly identical to doctor fish virus (DFV) and guppy virus 6 (GV6), 2 viruses isolated earlier from ornamental fish imported from Southeast Asia for the aquarium trade (Hedrick \& McDowell 1995). The significance of these findings in terms of the geographic range and mode of transmission of iridoviruses is discussed.

\section{METHODS}

Viruses and cell lines. Fathead minnow (FHM) cells, an epithelial cell line derived from tissue posterior to the anus of adult Pimephales promelas (ATCC CCL 42), and frog virus 3 were obtained from A. Granoff (St. Jude Childrens' Research Hospital, Memphis, TN). Iridoviruses isolated from doctor fish Labroides dimidatus, guppy Poecilia recticulata, and largemouth bass were obtained from R. Hedrick and were designated DFV (isolate No. F93-20 \#16), GV6 (isolate No. F93-20 \#6), and LMBV, respectively (Hedrick \& McDowell 1995. Plumb et al. 1996). For routine cell propagation, FHM cells were grown in closed tissue culture flasks at $26^{\circ} \mathrm{C}$ in Eagle's minimum essential medium (MEM) with Hank's salts (Sigma) supplemented with $5 \%$ fetal calf serum (Gibco-BRL). For metabolic labeling and plaque assay, FHM cells were cultured in 35 or $60 \mathrm{~mm}$ tissue culture dishes (Falcon) in Dulbecco's modified Eagle medium with $5 \%$ fetal calf serum in an humidified incubator in a $5 \% \mathrm{CO}_{2}-95 \%$ air environment.

Virus protein synthesis in FHM. Monolayers of FHM cells grown on $35 \mathrm{~mm}$ tissue culture dishes were infected with FV3, DFV, GV6 and LMBV at a multiplicity of infection (MOI) of 1 to 2 plaque forming units (PFU) cell-1. ${ }^{-1}$. Replicate cultures were labeled with methionine-free MEM (Sigma) containing $25 \mu \mathrm{Ci} \mathrm{ml}^{-1}$ ${ }^{35} \mathrm{~S}$ Imethionine (Amersham) from 18 to $20 \mathrm{~h}$ post in- fection (p.i.). Radiolabeled cells were lysed in $300 \mu \mathrm{l}$ of sample buffer (125 mM Tris- $\mathrm{HCl}[\mathrm{pH} 6.8], 2 \%$ sodium dodecyl sulfate [SDS], $10 \%$ glycerol, $0.02 \% 2$-mercaptoethanol, and $0.01 \%$ bromophenol blue), and boiled for 3 to 5 min prior to loading onto $10 \%$ polyacrylamide gels (Laemmli 1970). Following electrophoresis, gels were dried and ${ }^{35} \mathrm{~S}$-labeled proteins detected by autoradiography (Mao et al. 1997).

Analysis of viral DNA restriction fragment length polymorphisms (RFLP). Confluent FHM monolayers (60 $\mathrm{mm}$ dishes) were infected with iridoviruses as described above. At $18 \mathrm{~h}$ p.i., DNA was radiolabeled in media containing $25 \mu \mathrm{Ci} \mathrm{ml}{ }^{-1}$ [methyl ${ }^{3} \mathrm{H}$ ] thymidine (Amersham). At 21 h p.i., cells were washed with cold PBS, lysed in digestion buffer $(100 \mathrm{mM} \mathrm{NaCl}, 10 \mathrm{mM}$ Tris- $\mathrm{HCl}[\mathrm{pH} 8.0], 25 \mathrm{mM}$ EDTA, and $0.5 \% \mathrm{SDS}$ ), and incubated overnight in the presence of $100 \mu \mathrm{g} \mathrm{ml}^{-1}$ proteinase K. Subsequently, viral DNA was extracted with phenol-chloroform and digested with the restriction endonucleases HindIII, XbaI, KpnI, BamHI, HpaII, and $M s p I$ as directed by the manufacturer. Restricted DNA was analyzed by electrophoresis on $0.7 \%$ agarose gels (Maniatis et al. 1982), and radiolabeled fragments were detected by fluorography following impregnation with Enhance (New England Nuclear).

Amplification and sequence analysis of viral DNA. DNA templates were prepared from concentrated virus stocks. Virions were digested with $2 \mathrm{mg} \mathrm{ml}^{-1}$ proteinase $\mathrm{K}$ in the presence of $0.5 \%$ SDS for $4 \mathrm{~h}$ at $37^{\circ} \mathrm{C}$. Following protease treatment, viral DNA was extracted with phenol/chloroform and resuspended in TE buffer (10 mM Tris- $\mathrm{HCl}, \mathrm{pH}$ 8.0; 1 mM EDTA). Oligonucleotide primers were targeted to conserved regions of the genes encoding the iridovirus MCP and the viral DNA methyltransferase (MTase) (Kaur et al. 1995, Tidona et al. 1996, Mao et al. 1997). The sequence of individual primers are (5' to $3^{\prime}$ ): $M C P$ forward primer: GACTTGGCCACTTATGAC; MCP reverse primer: GTCTCTGGAGAAGAAGAA; MTase forward primer: TGTGGGCCAGTCCACCTTG; MTase reverse primer. GTAAGCGCAGTAATCCAACACG. PCR products $(\sim 500 \mathrm{bp}$ for MCP and 200 bp for MTase) were separated by electrophoresis on $0.7 \%$ agarose gels, purified, and cloned into the vector pCRII using the TA cloning method (InVitrogen). Both DNA strands were sequenced by the dideoxynucleotide chain termination method using the T7 Sequenase Quick Denature Plasmid Sequencing Kit or the ThermoSequenase Radiolabeled Terminator Cycle Sequencing Kit (Amersham) using vector-specific primers or the virus-specific primers listed above. A multiple alignment of the LMBV major capsid protein sequence with FV3, turtle virus 5 (TV5), Regina ranavirus (RRV), LCDV and chilo iridescent virus (CIV) was performed using the Clustal $\mathrm{V}$ algorithm (Higgins \& Sharp 1989) within MEGALIGN 
(DNASTAR, Madison, WI). Based on the alignment generated by MEGALIGN, a phylogenetic tree was constructed using the neighbor-joining method (Saitou \& Nei 1987) of DNASTAR. A multiple alignment of the LMBV viral DNA methyltransferase gene product with FV3 (Kaur et al. 1995), European catfish virus (ECV), DFV, RRV and LCDV (Tidona et al. 1996) was also performed using the same programs. Genbank accession numbers for the sequences used in the above multiple alignments are as follows: for the MCP_FV3, U36913; TV5, U82554; LCDV, L16683; CIV, M99395; LMBV, AF 080250; and RRV AF 080218; for the DNA methyltransferase-FV3, U15575; LCDV, L49526; ECV, AF100201; DFV, AF100202; LMBV, AF100199, and RRV, AF100200. RRV is a newly described ranavirus isolated from tiger salamanders in Saskatchewan (Bollinger et al. in press).

\section{RESULTS}

\section{Viral protein synthesis profiles}

To determine the taxonomic position of LMBV, we characterized this agent using 3 approaches shown previously to discriminate among iridovirus isolates (Mao et al. 1997). In the initial study, we examined the profile of viral protein synthesis in infected FHM cells. Because preliminary studies suggested similarity between LMBV and viruses isolated from doctor fish (DFV) and guppy (GV6), we compared protein synthesis patterns of LMBV to those from DFV, GV6, and FV3, the type species of the genus Ranavirus (Goorha 1995). As shown in Fig. 1, all 4 viruses synthesized a major polypeptide band of about $50 \mathrm{kDa}$, which is most likely the MCP. Moreover, the MCPs of LMBV, DFV, and GV6 migrated slightly slower than the corresponding protein from FV3, suggesting that the former possessed a higher molecular weight. Overall, the protein profiles from DFV, GV6, and LMBV were similar and could be readily distinguished from the FV3 pattern. However despite their overall similarity, several differences were detected by careful inspection of the gel. For example, among the higher molecular weight proteins (i.e. those whose molecular weight is greater than that of the MCP) marked differences were seen between LMBV and DFV/GV6. A unique band (indicated by the double arrowheads in Fig. 1) was detected in LMBV-infected cells, and among other high molecular weight species both quantitative (i.e. variations in band intensities) and qualitative differences were seen. Among proteins in the 22 to $43 \mathrm{kDa}$ range, additional qualitative and quantitative differences (indicated by filled squares in Fig. 1, Lane 5) were also seen. Although the significance of these differences

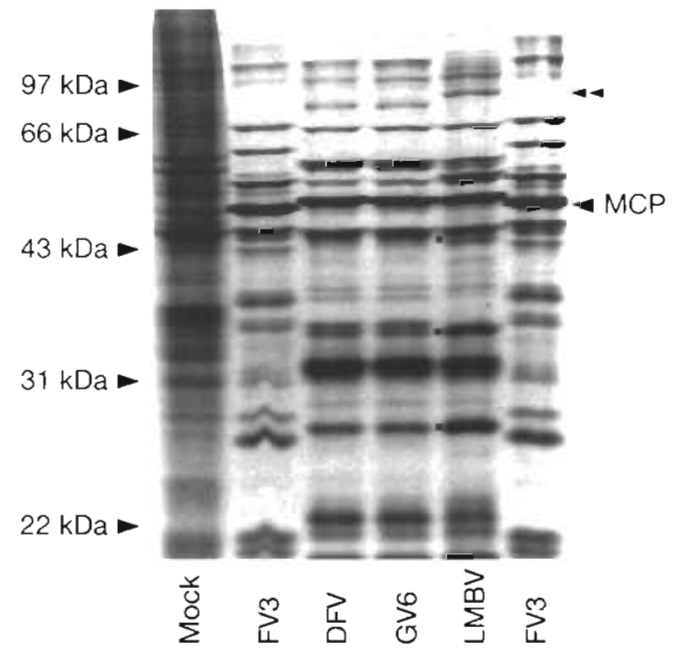

Fig. 1 Protein synthesis in virus-infected FHM cells. FHM cells, grown on $35 \mathrm{~mm}$ tissue culture plates, were infected with FV3, DFV, GV6, and LMBV at an MOI of 1 to 2 PFU cell ${ }^{-1}$ and labeled with methionine-free MEM containing $25 \mu \mathrm{Ci}$ $\mathrm{ml}^{-1}\left[{ }^{35} \mathrm{~S}\right]$ methionine from 18 to $20 \mathrm{~h}$ post infection. Lysates from radiolabeled cells were analyzed on $10 \%$ SDS-polyacrylamide gels and visualized by autoradiography. Molecular weight markers are shown to left of the first lane. The position of the major capsid protein (MCP) is indicated as is the position (marked by double arrowheads) of a high molecular weight band seen in LMBV, but not in DFV and GV6. Additional bands, differing among LMBV and DFV/GV6, are indicated by filled squares (Lane 5)

between LMBV and the other iridoviruses is not known, these results clearly indicate that LMBV can be readily distinguished from FV3, and that it is similar to, but distinct from, DFV and GV6.

\section{RFLP analysis}

Further evidence supporting this view comes from an inspection of RFLPs among these 4 viruses. As suggested by protein analysis, restriction fragments generated following cleavage of viral DNA with either HindIII or Xbal were remarkably similar among LMBV, DFV, and GV6 and readily distinguishable from those for FV3. However, despite their overall similarity, LMBV could be distinguished from DFV and GV 6 by the presence of 2 unique bands (identified by asterisks) following HindIII digestion (Fig. 2). LMBV and DFV showed similar profiles following Xbal digestion, whereas there were differences among the higher molecular weight fragments of GV6. Digests resulting from cleavage with $K p n I$ and BamHI were similar to those seen with HindIII in that DFV and GV6 showed identical profiles, whereas in digests of LMBV DNA, 1 (with BamHI) and 3 (with KpnI) unique bands were detected (data not shown). The sensitivity of LMBV 


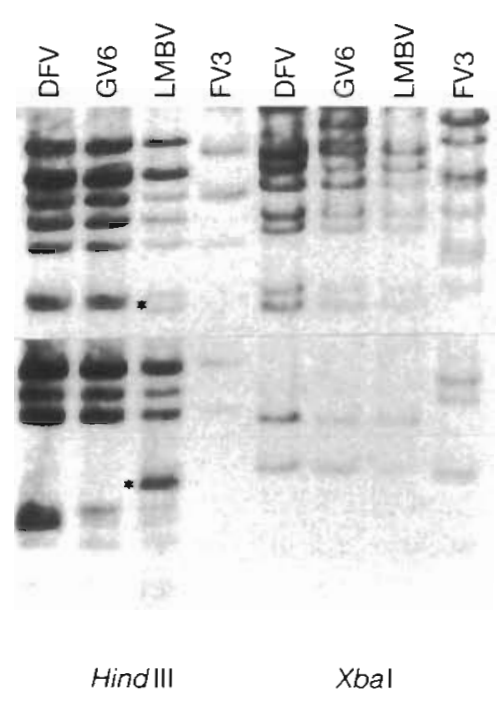

Fig. 2. Restriction fragment length polymorphisms (RFLP) of viral DNA. Confluent FHM monolayers $\{60 \mathrm{~mm}$ tissue culture dishes) were infected as described in the legend to Fig. 1 and labeled from 18 to $21 \mathrm{~h}$ post infection with media containing $25 \mu \mathrm{Ci} \mathrm{ml} l^{-1}$ [methyl ${ }^{3} \mathrm{H}$ ] thymidine. Radiolabled DNA was isolated as described in 'Methods' and digested with either HindIII or XbaI. Viral DNA was separated by electrophoresis on $0.7 \%$ agarose gels, and the viral DNA fragments visualized by fluorography. Two bands, differing among LMBV and DFV/GV6, are identified in Lane 3 by asterisks

DNA to cleavage by Hpall and MspI, isoschizomers which recognize the same target sequence (i.e. CCGG) but differ in their sensitivity to methylation, was also examined. Consistent with its classification as a vertebrate iridovirus, LMBV, as was DFV (Mao et al. 1997), was resistant to cleavage by HpaII, but cleaved by MspI (data not shown). Collectively, these results strengthen the protein findings and indicate that LMBV is closely related to, yet distinct from, DFV/GV6, and that its genome was highly methylated like other vertebrate iridoviruses (Goorha 1995).

\section{Sequence analysis: major capsid protein gene}

Although the above studies indicate a high level of similarity among LMBV, DFV, and GV6 they do not provide definitive information as to LMBV's taxonomic position within the family Iridoviridae. To determine the taxonomic position of LMBV within the genus Ranavirus, LMBV DNA was amplified, cloned, and subjected to sequence analysis. The 5' end of the major capsid protein gene was amplified by PCR using oligonucleotide primers specific for 2 highly conserved regions within the iridovirus family (Mao et al. 1996). A DNA fragment of $~ 500$ nucleotides was successfully amplified, cloned into pCRII, and its nucleotide se- quence determined. Consistent with the protein and RFLP profiles, both the nucleotide sequence and the inferred amino acid sequence of the viral DNA fragment were $98 \%$ identical to sequences from DFV and GV6. Within this region, DFV and GV6 were identical to each other, whereas LMBV differed from DFV and GV6 in 9 of 495 nucleotides and 3 of 165 amino acids (Fig. 3; Mao et al. 1997). Amino acid differences occurred between LMBV and DFV at positions 79, 80, and 148. In addition to marked sequence identity between LMBV and DFV, preliminary data suggested that the MCP of both LMBV and DFV possessed another feature in common-an NH-terminus which is truncated by the deletion of $\sim 6$ amino acids (data not shown).

To determine the taxonomic position of LMBV within the family Iridoviridae, a multiple alignment was performed using the deduced amino acid sequence of the amino-terminal end of the LMBV major capsid protein and corresponding polypeptides from several previously characterized iridoviruses (Mao et al. 1997). As shown in Fig. 3, LMBV is more closely related to FV3 and other members of the genus Ranavirus than to LCDV (genus Lymphocystivirus). Sequence similarity calculations showed LMBV was $80 \%$ identical to FV3, compared to $98 \%$ between FV3 and TV5, and $93 \%$ identity for RRV. In contrast, LCDV was only $47 \%$ identical to FV3, whereas CIV was $43 \%$ identical. This result is more clearly seen in Fig. 4, where a phylogenetic tree was constructed using the multiple alignment data shown in Fig. 3. As indicated by the phylogenetic analysis, LMBV most likely represents a unique ranavirus species distinct from FV3 and RRV.

\section{Sequence analysis: DNA methyltransierase}

To confirm that analysis of the MCP gene was reflective of overall sequence relatedness throughout the LMBV genome, the nucleotide sequence of a second gene, the viral DNA methyltransferase was determined. Using a primer set targeted to a conserved region within the FV3 and LCDV sequences (Kaur et al. 1995, Tidona et al. 1996), we successfully amplified a $\sim 200$ nucleotide fragment from LMBV. Comparison of its deduced amino acid sequence to those of other iridoviruses confirmed its close relationship to DFV/GV6 and its more distant relatedness to FV3, ECV, and LCDV (Fig. 5). At the nucleotide level, 4 nucleotide differences were detected between LMBV and DFV, but only 1 (amino acid \#66) of these resulted in an altered amino acid (Fig. 4). Within this 67 amino acid region, DFV and LMBV were $63 \%$ identical to FV3, whereas ECV showed $97 \%$ identity to FV3, RRV $96 \%$ identity to FV3, and LCDV only $56 \%$ identity 
Fig. 3. Deduced amino acid sequence and multiple alignment of the NH-terminus of the major capsid protein of LMBV and representative iridoviruses. The NH-terminal ends of the major capsid proteins of FV3, TV5, RRV, LMBV, DFV, CIV, and LCDV were aligned using the program MEGALICiN (DNASTAR). Amino acids that differ from the FV3 sequence are indicated by shading. Amino acid \#1 in this study corresponds to amino acid \#21 in the full-length FV3 MCP sequence (Mao et al. 1996). Amino acids corresponding to the sequences encoded by the oligonucleotide primers are not included in the analysis

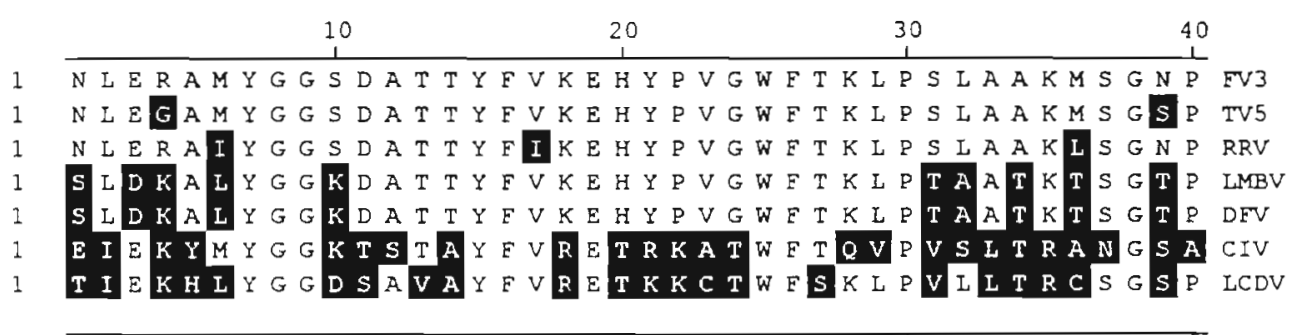

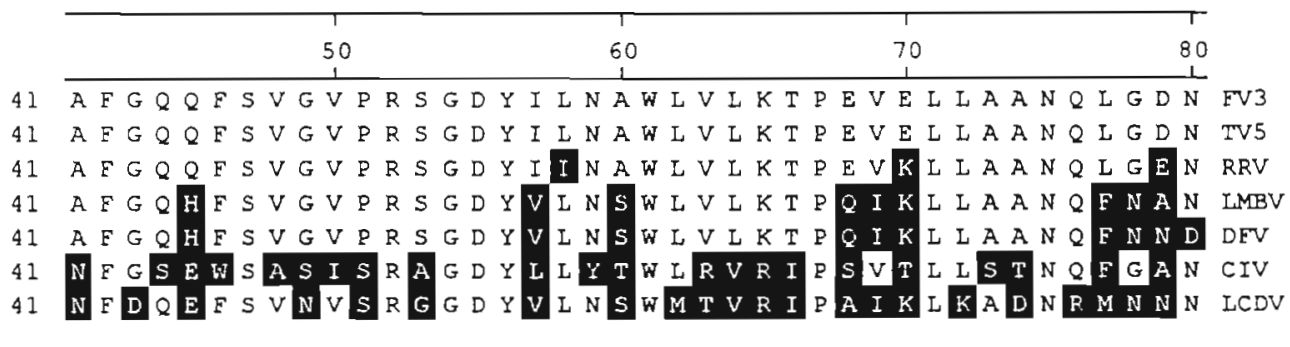

\begin{tabular}{cccc}
\hline 1 & 100 & 110 & 120
\end{tabular}

81 GTIRWTKNPMHN IVESVTLSFN DISAQSFNTAYIDAW SEY FV3 81 GTIRWTKN PMHNIVESVTLS FNDISAQSFNAAYLDAWSEY TV5 $81 G$ I I R T T KN P M H I I E N VNLS FNDISAQSFNTAYIDAW SE Y RRV 81 G I I R T T KN L M N VVEHAALS F N E I Q A Q Q F N T A F L D A W NE Y LMBV $81 G I I R W T K N I M H N V V E H A A L S F N E I Q A Q Q$ F N T A F L D A WNEY DFV 81 GRIRWCRNFMHNLIRECSITEN D L VAARFDHYHIDFWAAF CIV

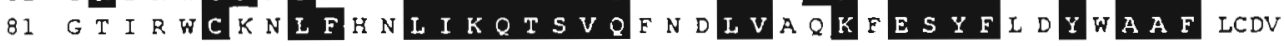

$\begin{array}{rrrr}130 & 140 & 150 & 160\end{array}$

121 TMPEAKRTGYYNMIGNTSDIINPA P A TGQDGARVLPAKNL FV3 121 TIPEAKRTGYYNMIGNTSDIIN PA P A T GQDGARVLPAKN L TV5 121 T M E AKR I G Y Y N I GNTS D L I N PAPA T GQNEARVL P A KN L RRV 121 TMPEAKRIGYYNMIGN T S D LVN PA P A T DQAGARVLPA KN L LMBV 121 T M P E AKR I G Y Y N M GN I S D L VN PAPATGQAGARVLPAKNL DFV 121 T T P A S KAVG Y D N I GNVSAIIQPQPVPVAPA TVSI PEADL CIV 121 SMCGSKRAG Y N N M I G N TI D M I Q P - . - V D H T G M L P E KV L LCDV
FV3

TV5

RRV

IMBV

DFV

CIV

LCDV to FV3. In addition, phylogenetic analysis, performed using data from the methyltransferease protein, generated essentially the same tree as that generated by the MCP sequences (data not shown). These results confirm that LMBV is closely related to, but distinct from, DFV and GV6, and suggest that genetic relatedness, as judged by sequence identity within the highly conserved MCP gene, is a valid approach for determining taxonomic position (Tidona et al. 1998).

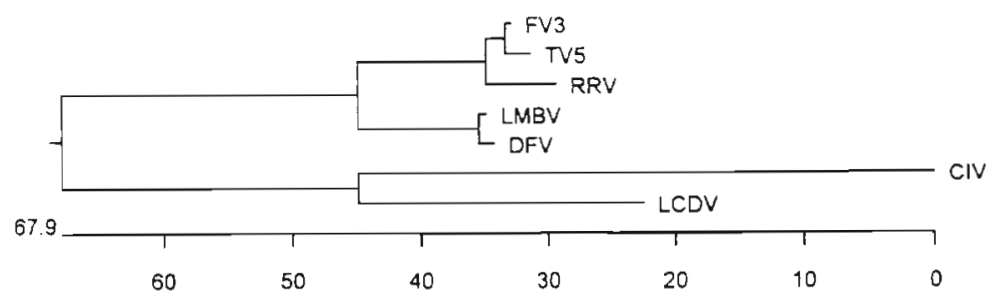

Fig. 4. Phylogenetic analysis of ranaviruses. Based on the alignment shown in Fig. 3, a phylogenetic tree was constructed using the neighbor-joining method of Saitou \& Nei (1987) as found within the MEGALIGN program of DNASTAR (Madison, WI). Branch length is proportional to the number of amino acid substitutions, which is indicated by the scale beneath the tree 


\begin{tabular}{|c|c|c|c|c|c|c|c|c|c|c|c|c|c|c|c|c|c|c|c|c|}
\hline & & & & & & & & & 10 & & & & & & & & & & 20 & \\
\hline C & $\mathrm{R}$ & $\mathrm{Y}$ & $F$ & $\mathrm{~S}$ & $\mathrm{~K}$ & L & $\mathrm{R}$ & $E$ & S & $N$ & I & G & $R$ & $G$ & G & $M$ & T & $\mathrm{K}$ & $\mathrm{K}$ & EV3 \\
\hline C & $R$ & Y & $\mathrm{F}$ & S & $\mathrm{K}$ & L & $R$ & $E$ & $S$ & $N$ & I & $G$ & $R$ & $G$ & G & $M$ & I & $\mathrm{K}$ & $\mathrm{E}$ & ECV \\
\hline C & $\mathrm{R}$ & $Y$ & $\mathrm{~F}$ & S & $\mathrm{K}$ & L & $R$ & E & S & $\mathrm{N}$ & I & G & $\mathrm{R}$ & $G$ & $\mathrm{G}$ & $M$ & T & $\mathrm{K}$ & $\mathrm{E}$ & RRV \\
\hline C & $\mathrm{R}$ & $\mathbf{F}$ & $F$ & $S$ & $\mathbf{R}$ & L & $\mathrm{R}$ & D & $S$ & $N$ & $T$ & G & $\mathrm{R}$ & $Y$ & $G$ & I & $T$ & $\mathrm{~K}$ & $E$ & DFV \\
\hline C & $\mathrm{R}$ & $F$ & F & $\mathrm{S}$ & $\mathrm{R}$ & L & $R$ & D & $\mathrm{S}$ & $N$ & $\mathrm{~T}$ & G & $\mathrm{R}$ & $Y$ & G & 1 & $\tau$ & $\mathrm{K}$ & $\mathrm{E}$ & LMBV \\
\hline $\mathrm{C}$ & $\mathrm{R}$ & $Y$ & F & $S$ & 1 & L & $R$ & $\mathbf{S}$ & $\mathrm{S}$ & $N$ & I & G & K & $\mathbf{K}$ & $G$ & $\mathbf{F}$ & $\mathbf{S}$ & $\mathrm{L}$ & $E$ & LCDV \\
\hline
\end{tabular}

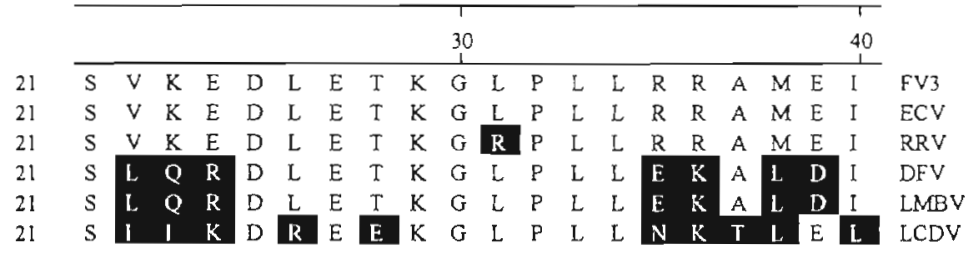

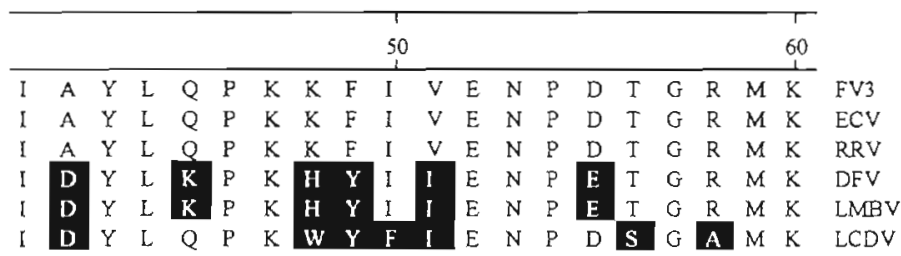

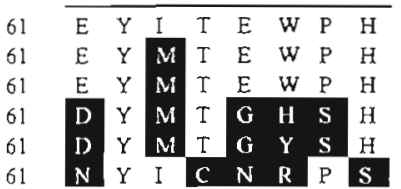

Fig. 5. Deduced amino acid sequence and multiple alignment of the DNA methyltransferease gene from LMBV and other iridoviruses. Multiple alignment of a partial amino acid sequence of the DNA methyltransferase genes of LMBV and 5 other iridoviruses was performed using the Clustal $\mathrm{V}$ program within MEGALIGN (DNASTAR). Amino acids corresponding to the oligonucleotide primers are not shown. Amino acid residues that differ from FV3 are indicated by shading. Amino acid \#1 in this figure corresponds to amino acid $\# 63$ in the LCDV sequence (Tidona et al. 1996)

\section{DISCUSSION}

The above study clearly indicates that LMBV is a member of the genus Ranavirus and is very similar to, but not identical with, viruses isolated previously from doctor fish (DFV) and guppy (GV6). This result casts doubt on our earlier hypothesis that iridovirus species/ strains are geographically isolated (Mao et al. 1997), and suggests that the apparent geographic clustering noted earlier might simply have been due to limited sampling Alternatively, the appearance of an 'Asian' virus in North America could reflect the inadvertent introduction of a foreign virus into native fish. At present, there is little evidence to support either hypothesis. Since surveys of iridoviruses are only in their infancy, it is not clear how many different iridovirus strains and/or species are circulating in a given geographical region. Furthermore, because ranavirus infections are often not confined to a single fish species, but can occur in different species of fish or in animals
FV3

ECV

RRV

DFV

LMBV

LCDV

from different taxonomic classes (Langdon 1989, Moody \& Owen 1994, Ahne et al. 1997, Mao et al. in press), iridovirus surveys need to include not only samples from other fish species, but also from other classes of aquatic animals (e.g. frogs, toads, salamanders, and turtles). For example, we have shown that an apparently identical iridovirus was isolated from sympatric stickleback fish and red-legged frog tadpoles in northern California (Mao et al. in press). In addition, Moody \& Owens (1994) demonstrated that Bohle iridovirus, a ranavirus which naturally infects the ornate burrowing toad, also experimentaliy infects barramundi fish. Given the promiscuous nature of iridovirus infectivity, it is possible that largemouth bass could have been infected by contact with aquarium fish which harbored a DFV/GV6-like agent and which had been introduced into the same reservoir as the infected bass. It should be noted that neither DFV nor GV6, which were isolated from apparently healthy fish, were pathogenic in channel catfish, and were only minimally pathogenic in rainbow trout and chinook salmon (Hedrick \& McDowell 1995). However, as shown by Langdon (1989), it may be possible that an iridovirus minimally pathogenic in one species can be responsible for serious infections in a second species. Transmission studies in which largemouth bass are challenged with DFV or GV6 would provide valuable information as to the host range of DFV/GV6like viruses and their likelihood of causing clinical disease in other species.

The above work suggests that the iridoviruses isolated from largemouth bass in South Carolina, and from doctor fish and guppies in southeast Asia, are most likely different isolates of a ranavirus species distinct from FV3 and EHNV. This taxonomic designation is based on 2 criteria. (1) The first is the suggestion of Ward (1993) that viruses with sequence identities within a given gene of less than $80 \%$ are members of different species rather than strains of the same species. (2) The second is the species definition offered by the International Committee on a Taxonomy of Viruses (ICTV) in which a viral species is defined as 'polythetic class of viruses that constitutes a replicating lineage and occupies a particular ecological niche' (Mayo \& Horzinek 1998). Consistent with the former guideline, sequence analysis of the LMBV major capsid protein and viral DNA methyltransferase genes showed only low identity to FV3 (80 and 63\% respec- 
tively) compared to ECV and RRV which were $>90 \%$ identical to FV3 in both genes (Figs. 3 \& 5; Mao et al. 1997). In addition, PCR assays failed to amplify sequences homologous to the FV3 $18 \mathrm{kDa}$ early protein, a protein thought to play a key regulatory role in FV3 replication (Willis et al. 1984) and which is highly conserved in ECV, RTV, RRV, and TV3 (Mao et al. 1997, and authors' unpubl. obs.). Taken together, sequence analysis strongly suggests that LMBV, DFV, and GV6 are different isolates or strains of a new ranavirus species. However, since other ranaviruses, e.g. the recently described Regina ranavirus (see below), may occupy a 'particular ecological niche', yet show greater than $90 \%$ sequence identity with FV3 within selected genes, further work is required to determine what percent genome identity/similarity defines a viral species. Clearly multiple criteria must be considered when determining the taxonomic position of a virus isolate. Sequence analysis, although very important and one of the more quantitative aspects of viral taxonomy, is only one facet in this decision. Finally, in keeping with the suggestion of Williams (1996) and the ICTV (Mayo \& Horzinek 1998), it may be more appropriate to designate this new virus species as Santee-Cooper ranavirus (SCRV) and to use the terms LMBV, DFV, and GV6 to refer colloquially to the different isolates/strains.

SCRV is the first ranavirus isolated in North America whose major capsid protein sequence is markedly different from FV3 and other similar viruses (Mao et al. 1996, 1997, in press). Recently, a second ranavirus distinct from both FV3 and SCRV has been isolated from morbid tiger salamanders Ambystoma tigrinum in Saskatchewan (Bollinger et al. in press) and Arizona (Jancovich et al. 1997). The former isolate has been termed RRV, while the latter has been designated A. tigrinum virus (ATV). These results indicate that ranavirus infections may be more widespread in North America than previously thought and may include a number of different species/strains. Future studies will be needed to determine the host and geographic range of these and other newly isolated ranaviruses and to obtain a clearer idea of their genetic complexity and disease potential.

Acknowledgements. This work was supported by funding from the US Department of Agriculture, NRICGP Award Nos. 94-37204-0853 and 95-37204-2225.

\section{LITERATURE CITED}

Ahne W, Schlotfeldt HJ, Thomsen I (1989) Fish viruses: isolation of an icosahedral cytoplasmic deoxyriboviurs from sheatfish (Silurus glanis). J Vet Med B 36:333-336

Ahne W, Bremont M, Hedrick RP, Hyatt AD, Whittington RJ (1997) Special topic review: iridoviruses associated with epizotic haematopoietic necrosis (EHN) in aquaculture World J Microbiol Biotechnol 13:367-373

Anders K (1989) Lymphocystis disease of fishes. In: Anne W, Krustak $E$ (eds) Viruses of lower vertebrates. SpringerVerlag, New York, p 141-160

Armstrong RD, Ferguson HW (1989) Systemic viral disease of the chromide cichlid Etroplus maculatus. Dis Aquat Org $7: 155-157$

Bollinger TK, Mao J, Schock D, Brigham RM, Chinchar VG (1999) Pathology, isolation, and preliminary molecular characterization of a novel iridovirus from tiger salamanders in Saskatchewan. J Wildl Dis (in press)

Goorha R (1995) Family Iridoviridae. In: Murphy FA, Fauquet CM, Bishop DHL, Ghabrial SA, Jarvis AW, Martell GP, Mayo MA, Summers MD (eds) Virus taxonomy: classification and nomenclature of viruses. 6th Report of the International Committee on Taxonomy of Viruses. Arch Virol Suppl 10:95-99

Hedrick RP, McDowell TS (1995) Properties of iridoviruses from ornamental fish. Vet Res 26:423-427

Hedrick RP, McDowell TS, Ahne W, Torhy C, de Kinkelin P (1992a) Properties of three iridovirus-like agents associated with systemic infections of fish. Dis Aquat Org 13:203-209

Hedrick RP, McDowell TS, Groff JM, Yun S, Wingfield WH (1992b) Isolation and some properties of an iridovirus-like agent from white sturgeon Acipenser transmontanus. Dis Aquat Org 12:75-81

Higgins DG, Sharp PM (1989) Fast and sensitive multiple sequence alignment on a microcomputer. CABIOS 5:151-153

Inouye $\mathrm{K}$, Yamano K, Maeno $Y$, Nakajima K, Matsuoka $M$, Wada Y, Sorimachi M (1992) Iridovirus infection of cultured red sea bream, Pagrus major. Gyobyo Kenkyu 27:19-27

Jancovich JK, Davidson EW, Morado JF, Jacobs BL, Collins JP (1997) Isolation of a lethal virus from the endangered tiger salamander Ambystoma tigrinum stebbinsi. Dis Aquat Org 31:161-167

Kaur K, Rohozinski J, Goorha R (1995) Identification and characterization of the frog virus 3 DNA methyltransferase gene. J Gen Virol 76:1937-1943

Laemmli UK (1970) Cleavage of structural proteins during assembly of the head of bacteriophage T4. Nature (Lond) 227:680-685

Langdon JS (1989) Experimental transmission and pathogenicity of epizootic haematopoietic necrosis virus (EHNV) in redfin perch, Perca fluviatilis L, and 11 other teleosts. J Fish Dis 12:295-310

Langdon JS, Humphrey JD, Williams LM, Hyatt AD, Westbury HA (1986) First virus isolation from Australian fish: an iridovirus-like pathogen from redfin perch, Perca fluviatilis. J Fish Dis 9:263-268

Maniatis T, Fritsch EF, Sambrook J (1982) Molecular cloning: a laboratory manual. Cold Spring Harbor Laboratory, Cold Spring Harbor, New York

Mao JH, Tham TN, Gentry GA, Aubertin AM, Chinchar VG (1996) Cloning, sequence analysis, and expression of the major capsid protein of the iridovirus frog virus 3 . Virology 216:431-436

Mao JH, Hedrick RP, Chinchar VG (1997) Molecular characterization, sequence analysis, and taxonomic position of newly isolated fish iridoviruses. Virology 229(1997): $212-220$

Mao JH, Green DE, Fellers G, Chinchar VG (1999) Molecular characterization of iridoviruses from sympatric amphibians and fish. Virus Res (in press)

Mayo MA, Horzinek MC (1998) A revised version of the international code of virus classification and nomenclature. Arch Virol 143:1645-1654 
Moody NJG, Owens L (1994) Experimental demonstration of the pathogenicity of a frog virus, Bohle iridovirus, for a fish species, barramundi Lates calcarifer. Dis Aquat Org 18: $95-102$

Plumb JA, Grizzle JM, Young HE, Noyes AD (1996) An iridovirus isolated from wild largemouth bass. J Aquat Anim Health 8:265-270

Pozet F, Morand M, Moussa A, Torhy C, de Kinkelin P (1992) Isolation and preliminary characterization of a pathogenic icosahedral deoxyribovirus from the catfish Ictalurus melas. Dis Aquat Org 14:35-42

Saitou N, Nei M (1987) The neighbor-joining method: a new method for reconstructing phylogenetic trees. Mol Biol Evol 4:406-425

Shah KV, Howley PM (1990) Papillomaviruses. In: Fields BN, Knipe DM (eds) Fields virology. Raven Press, New York, p 1651-1676

Tidona CA, Schnitzler P, Kehm R, Darai G (1996) Identifica-

Editorial responsibility: Jo-Ann Leong,

Corvallis, Oregon, USA tion of the gene encoding the DNA (cytosine-5) methyltransferase of lymphocystis disease virus. Virus Genes 12 : 219-229

Tidona CA, Schnitzler P, Kehm R, Darai G (1998) Is the major capsid protein of iridoviruses a suitable target for the study of viral evolution? Virus Genes 16:59-66

Ward CW (1993) Progress towards a higher taxonomy of viruses. Res Virol 144:419-453

Weissenberg R (1965) Fifty years of research on the lymphocystis virus disease of fishes (1914-1964). Ann NY Acad Sci 126:362-374

Williams T (1996) The iridoviruses. Adv Virus Res 46: $345-412$

Willis DB, Foglesong D, Granoff A (1984) Nucleotide sequence of an immediate-early frog virus 3 gene. J Virology 53:905-912

Wolf K (1988) Fish viruses and fish viral diseases. Comstock Publishing Associates, Ithaca

Submitted: November 30, 1998; Accepted: March 25, 1999 Proofs received from author(s): June 21, 1999 